International Journal of Agriculture, Environment and Bioresearch

Vol. 5, No. 05; 2020

ISSN: $2456-8643$

\title{
LAND COVER AND LAND USE CHANGE IN THE MARA RIVER BASIN: A GEOSPATIAL APPROACH
}

\author{
Ayuyo Isaac Ongong'a*, Krhoda George. O. and Mukhovi Stellah \\ Department of Geography and Environmental studies, University of Nairobi, P.O. Box 30197-00100, Nairobi, \\ Kenya \\ https://doi.org/10.35410/IJAEB.2020.5554
}

\begin{abstract}
Mara River basin forms part of the Upper Nile catchment and critical for the Maasai Mara Serengeti ecosystem. Its rich mix of land cover types including natural forests andopen savanna are threatened by unplanned land uses in the upper catchment. The objective of the study was to determine the nature and extent of change in land cover and land use between 1984 and 2016. Unsupervised classification of dry season Landsat imageries for 1984, 1995, 2003, 2011 and 2016 was conducted using ENVI 5.0 and ArcGIS 10.5 with eight land cover types including forestland, shrub land, grassland, cropland, wetland, water body, built-up area and bare land. Post-classification area analysis of the thematic mapsand overlay operations of classified images was conducted for change detection. The results showed that forestland, shrub land and grassland are decreasing in extent at the expense of cropland and built-up areas. Wetlands and water bodies had no definite trends of change. Between 1984 and 2016, forestland, shrub land and grassland decreased by $1.3 \%, 6.82 \%$ and $5.51 \%$ with cropland and built-up area increasing by $8.22 \%$ and $0.07 \%$ respectively. These changes have negative impacts on the Mara River hydrological regimes and on the environment with implications for livelihoods and biodiversity. There is need for proactive measures to mitigate or control the adverse impacts on this important transboundary resource.
\end{abstract}

Keywords: Land Cover/Use Change, Mara Basin, East Africa.

\section{INTRODUCTION}

Changes in the land cover and land use types are the main cause of the changes being witnessed in the environment and ecology globally, driven by changes in the energy composition, the biogeochemical cycles and the hydrological cycles of the earth system[1] [2]. These changes have affected the ability of the biophysical systems to support the many human needs[3]. Land use is expressed by the human actions practiced in a physical environment for socio-economic wellbeing [4] and therefore is dynamic and has changed over time with increase in population resulting in variations in the elements of the hydrological cycle[5] [6]. Changes in land use that lead to reduction in forest cover and general environmental quality such as urbanization, rural settlement, infrastructural development and farming have impact on rainfall, temperature and humidity and therefore may modify the climate of a given area[7] [8] [9]. This is because loss in 
forest cover tends on one hand to increase storms and flood risks, surface runoff and soil erosion as well as reduction in evapotranspiration rates, infiltration and base stream flow[10] [11] [12]. Anthropogenic land cover changes are common and classified as either modification or conversion of the original cover type[13]. Modification of land cover simply refers to changing the condition of the original cover such as effecting significant changes in the forest cover and density by changing the management of forest resources [14]. Conversion is a change in the types of land cover, say from forestland to cropland. Conversion has been the focus of many global change research agendas due to the manner in which the global forests are being lost to other cover categories, mainly farms, urban settlements and roads infrastructure [15]. The loss occasioned on the global tropical rainforests due to timber harvesting and creation of land for agriculture has become a popular topic in the international fora on global warming and climate change[8].

Despite all these global efforts to conserve the forest ecosystem, little is on the offing at national levels to conserve the forest resources, especially in the developing countries where deforestation is still an issue that needs to be addressed for sustainability in the biophysical systems.Land cover and land use dynamics on river flows have been observed to be more evident in arid and semi-arid lands (16). Low flows are more sensitive to the changes in land use and land cover[2]. [17] recognized the changes in land cover and land use to be affecting both the river flow regimes and the annual mean flows. On their part, [18] concluded that increased streamflow in the Mississippi River was mainly due to an increase in base flow as a result of land cover /land use changes. Mara River basin, a typical farming-pastoral-conservation zone in Kenya and Tanzania, has shown increasing trends of droughts, where streamflow decreases dramatically even during the rainy seasons with very low base flows.

The main land cover/land use types in Mara Basin include grassland, shrub land, forestland and wetlands, which have faced significant modification and conversion over the last 40 years with increase in population, which has made the basin very vulnerable to their negative impacts [11]. The study by[19] indicated that conversion of forestland to cropland resulted in a $3.2 \%$ reduction in the total annual river flow volumes while reduction of $20 \%$ in rainfall translated to a 46\% annual flow reduction in the Mara basin. The study also discovered that base flows reduce significantly during dry seasons. Decreased stream flows could cause serious impact on the environment, the river and estuary ecosystems and, socioeconomic systems.

In this paper, we used a geospatial approach to map temporal land cover and land use changes in the Mara that would help in assessing the hydrological responses to land cover and land use changes. This paper attempts to determine the nature, extent and rate of change in land cover and land use in the Mara River basin with a view to evaluating the effects of these changes on the Mara River hydrological regimes. This information is crucial for effective planning and management of water resources for sustainable development, especially in water sensitive basins such as the Mara. The study had two objectives namely;a) to analyze the land cover and land use change in the Mara River Basin and b)to assess the trend and magnitude of the land use/cover changes.

\section{MATERIALS AND METHODS}

\subsection{Study Area}


Mara river basin is a trans-boundary resource between the two East African countries of Kenya and Tanzania and is located between longitudes $33^{\circ} 47^{\prime} \mathrm{E}$ and $35^{\circ} 47^{\prime} \mathrm{E}$, and latitudes $0^{\circ} 38^{\prime}$ $\mathrm{S}$ and $1^{\circ} 52^{\prime} \mathrm{S}$ [Figure 1].

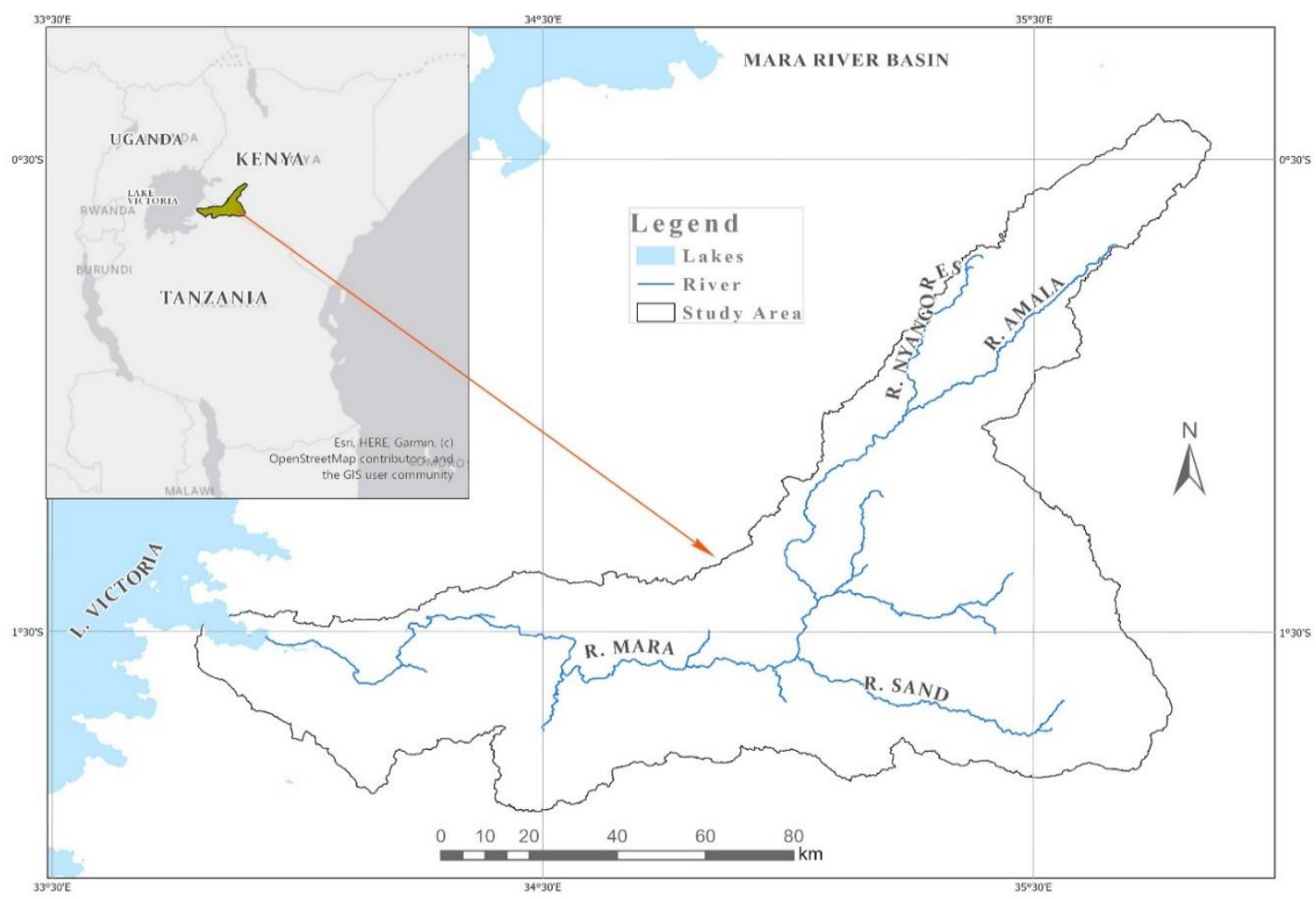

Figure 1: Location of Mara River Basin astride Kenya and Tanzania (Source: [20]

Mara River originates from the Napuiyapui swamp in the Mau Forest Complex at an altitude of 3057 meters and covers a distance of $395 \mathrm{~km}$ before it pours its water into Lake Victoria at Musoma Bay at an elevation of 1106 metres. The Mara River basin drains an area of $13,750 \mathrm{~km}^{2}$ out of which, $8,941 \mathrm{~km}^{2}(65 \%)$ is in Kenya while 4,809 $\mathrm{km}^{2}(35 \%)$ is in Tanzania. The physiography consists of the Mau Escarpment to the north, Soit Ololo Escarpment to the west, Loita and Sannia plains to the east and southeast respectively. The basin climate regime such as rainfall, temperature, river flow, surface runoff, floods and droughts are dependent upon geographical location within the tropics and the physiographic characteristics.

Rainfall varies with altitude with mean annual rainfall ranging from 1,000-1,750 $\mathrm{mm}$ in the Mau Escarpment, 900-1,000 $\mathrm{mm}$ in the middle rangelands to $700-850 \mathrm{~mm}$ in the lower Loita hills and around Musoma. Rainfall seasons are bi-modal with the long rains falling between March and May while the short rains are in the months of September to November. The basin has a mean annual temperature of $25^{\circ} \mathrm{C}$ that increases with decrease in altitude, the mean monthly maximum temperature stands at $27-28^{\circ} \mathrm{C}$.

The rangelands in the Mara Basin support diverse species of wildlife, which together with livestock production supports the livelihoods of the Maasai community. The humid and subhumid areas support agricultural production mainly wheat, maize, barley, among other food 
crops grown by both large scale and smallholder farmers accounting for about $62 \%$ of the households[23]. Tourism notwithstanding is an important economic activity as exemplified by the Maasai Mara Game Reserve and the Serengeti National park on the Kenyan and Tanzanian sides respectively. These ecological and economic functions however, may not thrive for long due to the accelerated loss of vegetation cover in the upper catchments and the conversion of pastoral land into plantation agriculture due to land privatization[11]. The accompanying land degradation and reductions in water levels as population pressure increases is posing a big threat to the river flows and the ecosystems[11] [24] [25] [26].

\subsection{Methods}

\subsubsection{Data Sources}

Mapping of land cover and land use change utilized a mosaic of available high spatial resolution, cloud-free snapshots of Landsat TM, ETM and ETM+, for the years 1984, 1995 2003, 2011 and 2016 respectively [Figure 2 and

Table 1]. Specifically, they include the Landsat 5 Thematic Mapper (TM) images at Band 2

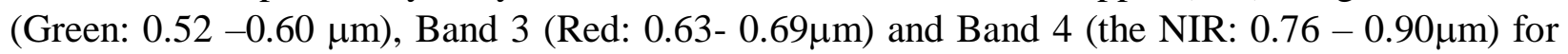
the years 1984 and 1995. Landsat 7, Enhanced Thematic Mapper Plus (ETM+) images at the same bands for the years 2003 and 2011 and Landsat 8, also ETM+ but with an extra sensor facility, (Operational Land Imager and Thermal Infrared Sensor that was used for the year 2016. Figure 2 shows the Landsat grid scene coverages in which three of them namely: P169R060, P169R061 and P170R061 cover the Mara River basin.

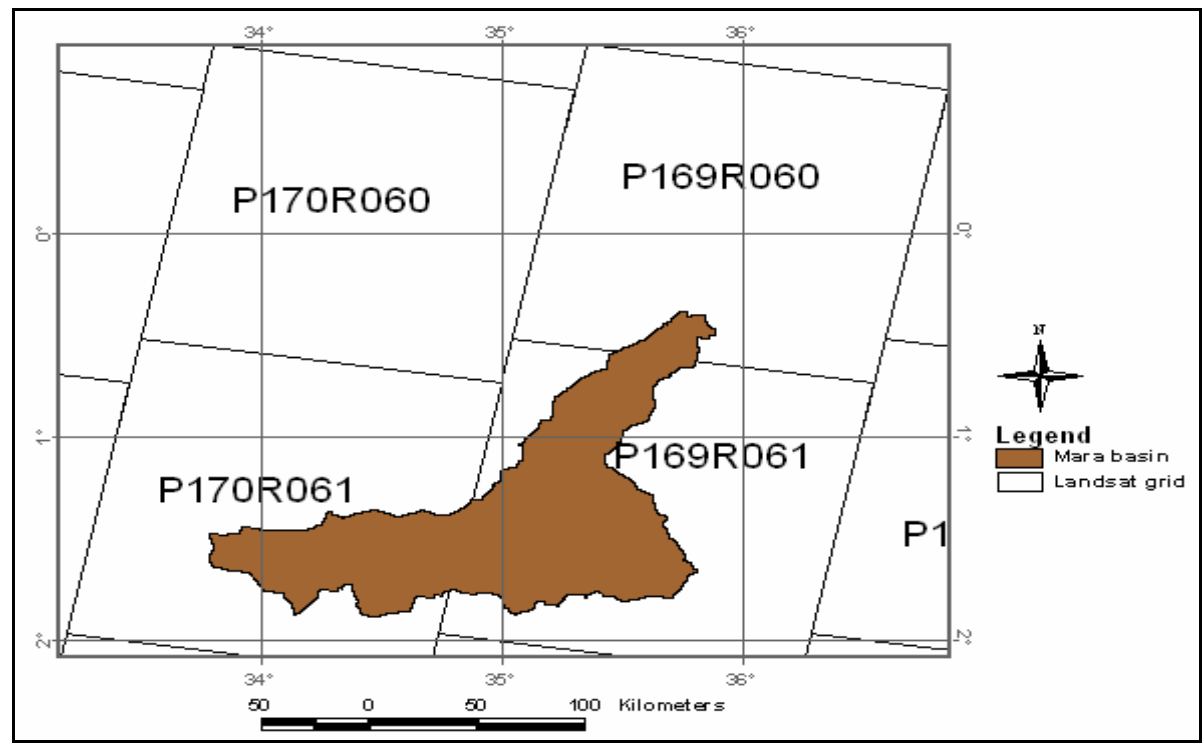

Figure 2: Landsat grid scene coverage for Mara River Basin.

Each set of the three grid scenes formed a mosaic for each year of study meaning that, for the years 1984, 1995, 2003, 2011 and 2016, the total number of imageries required were fifteen as shown in 
Table 1.

Table 1: Image scene identification used in land cover classification

\begin{tabular}{|l|l|r|}
\hline Year & Landsat series & \multicolumn{1}{c|}{ Image Scene ID used } \\
\hline $\mathbf{2 0 1 6}$ & Landsat 8 & lc81690602016047lgn00 \\
\hline & & lc81690612016047lgn00 \\
\hline & & lc81700612016054lgn00 \\
\hline $\mathbf{2 0 1 1}$ & Landsat 7 & lt71690612011017mlk00 \\
\hline & & lt71700612011184mlk01 \\
\hline $\mathbf{2 0 0 3}$ & Landsat7 & le71690602003067sgs00 \\
\hline & & le71690612003067sgs00 \\
\hline & & le71700612003138asn00 \\
\hline $\mathbf{1 9 9 5}$ & Landsat 5 & 1t51690601995037xxx01 \\
\hline & & 1t51690611995037xxx01 \\
\hline & & lt51700611995092xxx02 \\
\hline $\mathbf{1 9 8 4}$ & Landsat 5 & lt51690601984183xxx09 \\
\hline & & lt51690611984183xxx09 \\
\hline & & 1t51700611984254aaa01 \\
\hline
\end{tabular}

The Landsat imageries were used due to their combination of Red, Green and Near InfraRed bands thatenhances the delineation of different vegetation categories, the built-up areas, the water bodies as well as the bare surfaces. Its spatial resolution of 30-metre pixel and seven band radiometric resolutions make it suitable for land cover classification and, with its instantaneous field of view of 15 degrees, it has a swath width of $185 \mathrm{~km}$ [27], which enables it to cover large areas and therefore capture many features within one scene.

\subsubsection{Image Processing and Analysis}


Processing digital datasets involved image thinning and band compositing as well as standard deviation stretching and geometric registration of the 1984, 1995, 2003, 2011 and 2016 Landsat TM, Landsat ETM and Landsat ETM+ imageries respectively. The wavelength bands: 4, for infrared; 3, for red and 2, for green, wereusedto form the NIR false colour composite of red, green and blue colour (RGB) channels. Spectral resolutions for blue, green, red and infrared bands are $0.45-0.52,0.520 .60,0.63-0.69$ and $0.76-0.90$ micrometers respectively. Their radiometric sensitivity is $0.8,0.5,0.5$ and 0.5 for blue, green and red and near infrared bands respectively. These false colour composites were used in land cover/use mapping and visualization with an aim to correcting any errors where necessary. The composite maps were used in geotiff format for easy display and manipulation under ENVI 5.0 and ArcGIS 10.4 softwares. Standard deviation stretching was done on the image composites to improve visualization.

\subsubsection{Geo-referencing of the Imageries}

Landsat ETM+ image of 2016 was geo-referenced using 1:50, 000 topographic maps of the study area and eleven (11) ground truthing points, selected based onthe unrectified images and on the land cover types. These points, with their respective geographic coordinates on the topographic maps were used for spatial interpolation using a first order polynomial transformation. Intensity interpolation, the relocation of the brightness values of each pixel in the unrectified image to its appropriate location in the rectified image, was performed using the Nearest Neighbour algorithm, an exercise that was repeated for imageries of 2011, 2003, 1995 and 1984.

\subsubsection{Generating NIR False Colours Using Imageryof 1984}

ENVI 5.0 image processing software was used to stack the various scenes required for the image thinning and image mosaicking. Clipping the basin boundary was done using the DEM of the basin and imagery of 1984, using mask tool in ArcGIS. The process was necessary in order to come up with the Landsat near infrared false colour imageries and saved in Geodatabase. SBQ format imageries to be clipped were opened one at a time on ENVI 5.0 viewer window. While in the same viewer, the shape file of the area of interest showing Mara River basin boundaries was displayed followed by clipping the SBQ format imagery based on Mara boundary using ENVI image clip tool to create an output image file, which was then saved. This procedure was performed consecutively for all false colour Landsat imageries starting with 1995, 2003, 2011 then 2016, ready for developing the image classification scheme, image classification and generation of the land cover maps.

\subsubsection{DevelopingImage Classification Scheme}

Unsupervised Classification approach was applied with topographic maps and ground truthing points of the area for validation of the cover types and location for accuracy. The first step involved the development of an appropriate classification scheme. To do this, the study used the Landsat imagery of 2011 and topographical map of 2010 at 1: 50,000 of the Mara Basin to identify details that appeared on both the topographical map and on the imagery according to spectral signatures and recorded them down. The eight (8) classes used for this study were 
Forestland, shrub land, grassland, wetland, water body, built-up area, and bare land. After the signatures for each land cover type had been defined, the software used these signatures to classify the remaining pixels. Thus, for each class outlined, mean values and variances of the DNs for each band used to classify them were calculated for all the pixels enclosed in each site. During ground truthing, the same details were validated for consistency and completeness by comparing the thematic map details and the ground details as per ground truthing coordinates.

\subsubsection{Image Classification and Generation of Land Cover Maps}

In delineating area of interest for the generation of information on spatial changes in the land cover, the Landsat Enhanced Thematic Mapper Plus of 2016 was vectorized under ArcGIS environment. The Mara basin (area of interest), was clipped from the Landsat false colour imageries under ENVI 5.0 software environment and using the Digital Elevation Model of the basin for every image according to the year of acquisition - 1984, 1995, 2003, 2011 and 2016. These were used to produce static land cover and land use maps of the Mara River basin as at the dates of the imageries. Starting with the 1984 imagery and using the signatures developed for each land cover category, the software automatically classified all the remaining pixels giving new polygon themes. That is, forestland, shrub land, grassland, wetlands, water bodies, built-up area and bare land with their quantities. This resulted in Mara River spatial boundary delineation as at that date of 1984 imagery. The Unsupervised Classification applied Minimum Distance and the results were refined with smooth kernel size of 3 and aggregate minimum size of 9 , which were then transferred and stored in a GIS database. Landsat TM for 1995 and Landsat ETM+ for 2003, 2011 and 2016 imageries were also generated in the same way.

\subsubsection{Land Cover Change Detection}

In order to establish the land cover changes that occurred within the study area between 1984 and 2016, a post-classification change detection analysis of the 5 dates of imageries was performed using ENVI 5.0 remote sensing software. For this purpose, the attribute tables for each thematic map (1984, 1995, 2003, 2011 and 2016) were analyzed under "post classification area comparison". The change detection was also done through overlay operations using unclassified images as opposed to thematic maps because thematic maps are in vector format and therefore cannot overlay the way images do. Overlay operations were performed on all the delineated and clipped Mara River basin boundaries in ArcGIS environment. The registered 1984 imagery was overlaid on 1995 image and the changes in land cover produced under ENVI 5.0 processing software. The exercise was repeated by overlaying 1995 and 2003 imageries followed by the 2003 and 2011 and finally, 2011 and 2016 imageries. Four "from-to" change matrices were obtained for the 1984-1995, 1995-2003, 2003-2011 and 2011-2016 periods, in that order. This study laid emphasis on changes in forest cover, shrub land and grassland since these are the cover types with impacts on rainfall and river discharge. Understanding the expanse of cropland is also of significance in the basin because they are new interventions due to population pressure with serious impacts on discharge as farming activities result in increased use of water especially for irrigation.

\subsection{Land Cover Map Accuracy Assessment}


Image classification was assessed for accuracy to correct any errors and omissions that might have occurred in the classification process. The accuracy assessment was done by creating and using a classification error matrix to compare the classification results with the ground truthing data obtained during fieldwork [Table 3]. The error matrix was evaluated by means of Kappa analysis, a discrete multivariate technique that yielded the statistic ( $\mathrm{K}$ hat Coefficient of Agreement) estimate to measure the agreement between the remote sensing-derived classification map and the reference data. The assessment was done by selecting the menu item classifier>accuracy assessment and then importing the ground truthing coordinates from an Excel file which was already saved in text format. According to[28], whatever the algorithm used, the spectral image classification always results in accuracies ranging between $50 \%$ and $75 \%$, depending on the number of available image registrations, the quality of the ground truth and the number of considered change classes. In this case, overall classification accuracy $=$ $72.5 \%$ and Overall kappa statistics $=0.7245$.

Table 2: Accuracy Assessment Results for 2016 Image Classification

\begin{tabular}{|l|l|l|l|l|l|}
\hline CLASS & $\begin{array}{l}\text { REFERENC } \\
\text { E TOTALS }\end{array}$ & $\begin{array}{l}\text { CLASSIFIE } \\
\text { D TOTALS }\end{array}$ & $\begin{array}{l}\text { CLASSES } \\
\text { CORRECTE } \\
\text { D }\end{array}$ & $\begin{array}{l}\text { (\%) } \\
\text { PRODUCER } \\
\text { S } \\
\text { ACCURACY }\end{array}$ & $\begin{array}{l}\text { (\%) USERS } \\
\text { ACCURAC } \\
\text { Y }\end{array}$ \\
\hline $\begin{array}{l}\text { Forestlan } \\
\text { d }\end{array}$ & 5 & 4 & 4 & 72.5 & 100 \\
\hline $\begin{array}{l}\text { Shrub } \\
\text { land }\end{array}$ & 5 & 4 & 4 & 71.0 & 100 \\
\hline Grassland & 5 & 4 & 4 & 74.2 & 100 \\
\hline Cropland & 5 & 3 & 3 & 69.9 & 100 \\
\hline Wetland & 5 & 3 & 3 & 73.1 & 100 \\
\hline $\begin{array}{l}\text { Water } \\
\text { body }\end{array}$ & 5 & 4 & 4 & 75.0 & 100 \\
\hline $\begin{array}{l}\text { Built-up } \\
\text { Area }\end{array}$ & 5 & 3 & 3 & 70.5 & 100 \\
\hline Bare land & 5 & 2 & 2 & 74.0 & 100 \\
\hline
\end{tabular}

The Kappa coefficient expresses the proportionate reduction in error generated by a classification process compared with the error of a completely random classification[28] [Equation 1].

$$
\text { Kappa coef ficient }=N \frac{\sum_{i=1}^{N} x_{i i}-\sum_{i=1}^{P}\left(x_{i+} * x_{+i}\right)}{N^{2}-\sum_{i=1}^{g}\left(x_{i} * x_{+i}\right)}(1)
$$


$\mathrm{r}=$ number of rows in the error matrix; $X_{\mathrm{ii}}=$ number of observations in row I and column I The diagonal element), $\mathrm{X}_{\mathrm{i+}}=$ marginal totals of row I; $\mathrm{X}_{+\mathrm{i}}=$ marginal totals of column I; $\mathrm{N}=$ Total number of observations.

The resultant value was then evaluated and was found to represent a good agreement between the remote

sensing derived map and the reference data from the field

\section{RESULTS}

\subsection{Land Cover and Land Use Change in the Mara River Basin}

The results of the overlay operations revealed the spatio-temporal variations and change in land cover and land use in the Mara River basin. The changes within and cross the eight classes and the areas in each class that did not change are clearly shown. If we take grassland for example, the maps show the areas covered by grass that have changed and the areas that remained undisturbed over the period in question. Overlay technique reveals in a nutshell, desirable and undesirable changes in land cover and land use that can be a leading indicator to the resource managers of the impending danger should no action be taken to reverse the trend. The overall spatio-temporal changes between 1984 and 1995, 1995 and 2003, 2003 and 2011 as well as between 2011 and 2016 are on [Figure 3, Figure 4, Figure 5, and Figure 6].

. Between 1984 and 1995, 79.24\% of the total coverage did not change to any class. Major changes to other classes were under grassland and shrub land, 8.55 and $6.94 \%$ respectively. This should be an expected scenario because the basin is largely a rangeland, it is understood that, the shrub land and the grassland form about $85 \%$ of the total cover that did not change. Forestland on its part, changed by $0.71 \%$, this is a very significant change in forest cover given the proportion of forestland in the basin. Cropland, which is continually increasing in the basin changes by $3.81 \%$ to other cover types while wetland and water body changed by $0.2 \%$ and $0.02 \%$ respectively. The minor cover types at the time, built-up land and bare land changed by $0.06 \%$ and $0.005 \%$ over the period (Figure 3 ). These changes are purely human interventions in the basin, as population increased. 


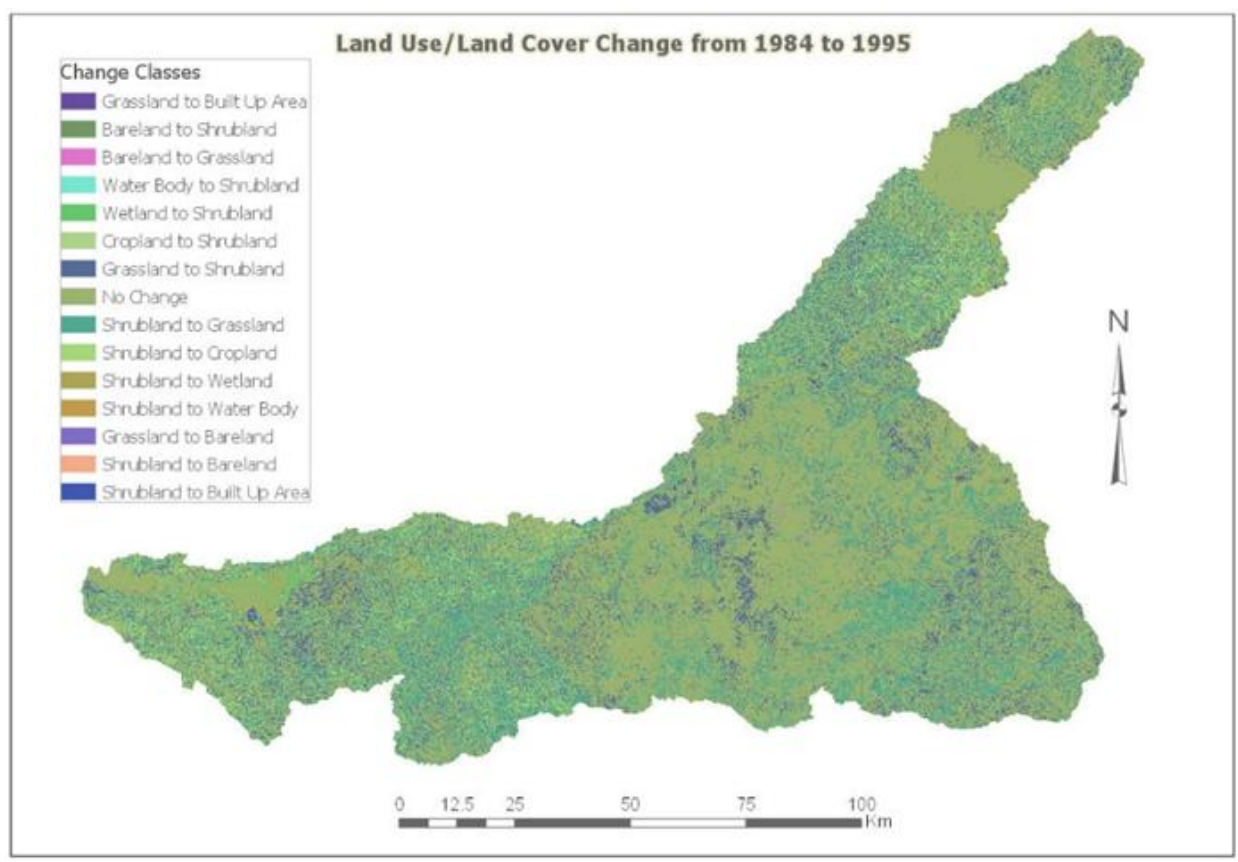

Figure 3: An overlay of 1984 and 1995 Maps (Source: Researcher, 2018)

Between 1995 and 2003, the same trends of change in land cover and land use continued. This time, the land cover types that did not change accounted for $80.06 \%$ of total cover types with major change recorded under shrub land, $6.29 \%$. Grassland followed closely, changing by $6.00 \%$ and cropland $4.25 \%$,(Figure 4 ).

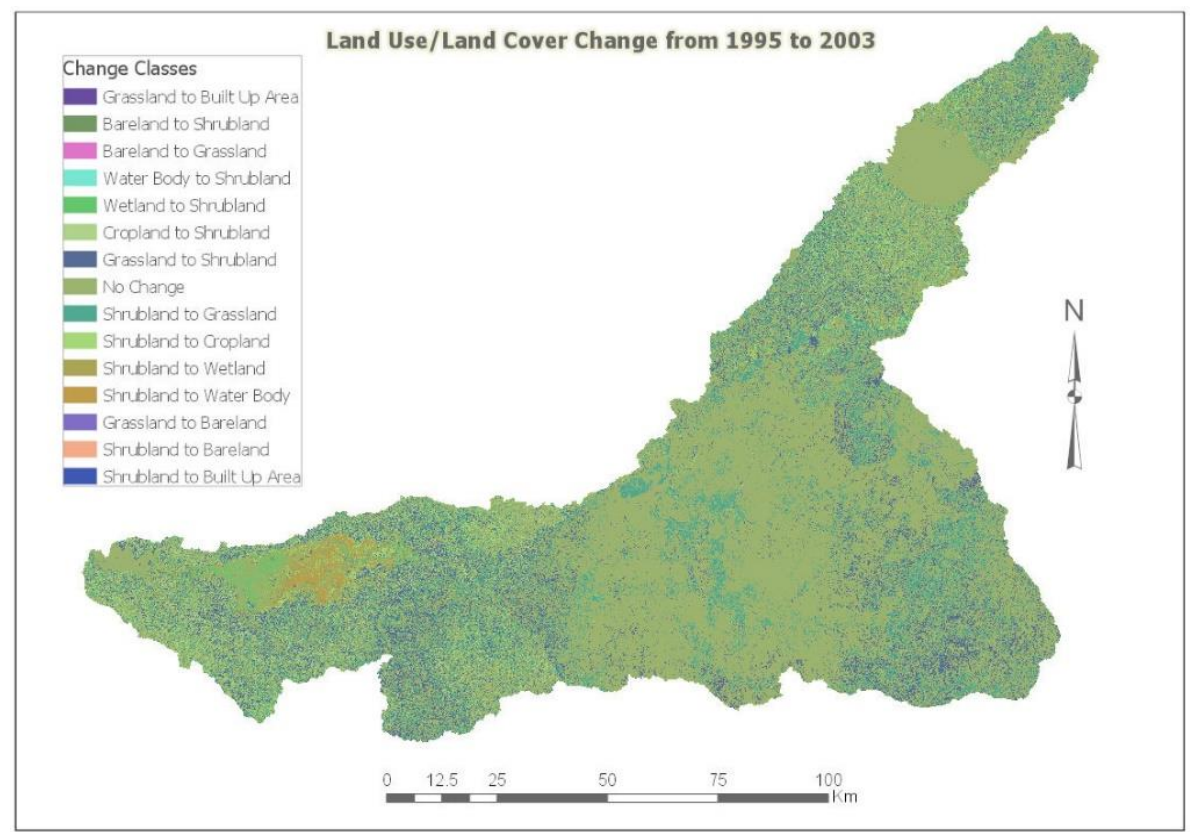

Figure 4: An overlay of 1995 and 2003 Maps (Source: Researcher, 2018) 
Forestland changed by $1.08 \%$, wetlands, $1.7 \%$ while water body recorded $0.67 \%$ change. Builtup and bare land both changed by less than $0.1 \%$. Forestland, grassland, shrub land are reducing at an alarming rate thereby compromising many systems due to the hydrological responses to land cover and land use changes.

In the same way, the period between 2003 and 2011 registered $78.80 \%$ of cover types that did not change. Shrub land, for the second time, registered a higher figure in change than grassland, $8.08 \%$ and $6.38 \%$ respectively. Cropland experienced a change of $5.20 \%$ to other cover types, which could be due to some farms lying fallow for later use or converted to built-up areas. Such activities allow the farms to acquire other cover categories (Figure 5). Equally, imageries taken during dry periods tend to record farms like waste or bare land.

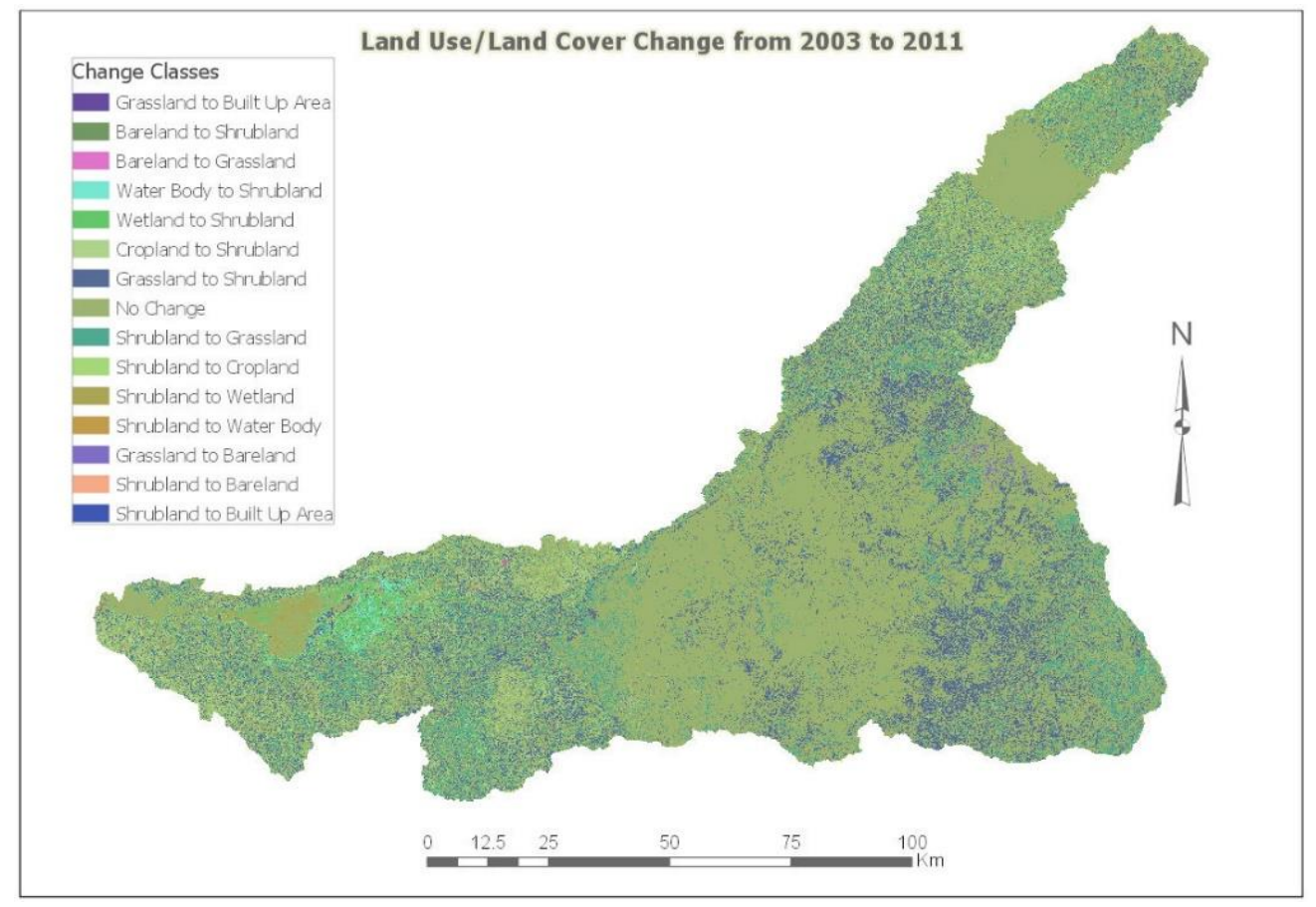

Figure 5: An overlay of 2003 and 2011 Maps (Source: Researcher, 2018)

Over this period, forestland changed by $1.17 \%$., which, in terms of the area under forest in the basin, these changes in forest cover are very significant and have implications on rainfall formation and temperature regulations in the Mara basin and its environs. Reduction in areas under forests, shrubs and grass reduces rates and amounts of evapotranspiration due to reduced leaf coverage, hence less moisture in the atmosphere and therefore poor formation of rainfall over the Mara. Wetlands changed by $0.26 \%$, water body, $0.05 \%$, built-up area, $0.03 \%$ and bare land $0.04 \%$. Generally, wetlands are changing at higher rates than water bodies because human beings encroach wetlands for a number of services including farming and grazing more than they do for water bodies. On the same note, changes in bare land are a function of man and nature, although man is accelerating the attributes of nature.

During the last period of study, 2011 to 2016, the cover types that did not change occupied $81.58 \%$. On the average, $79.97 \%$ of the total land cover types did not change between 1984 and 2016. During the 2011-2016 period, shrub land recorded almost $6 \%$ change to other cover types 
while grassland had slightly more than $5 \%$ change. Cropland changed by about $5.7 \%$, forestland, $1.48 \%$, wetlands, $0.63 \%$, water body, $0.06 \%$, built-up area, 0.02 and bare land $0.03 \%$ [Figure 6].The next section gives the overall change in each cover type over the study period.

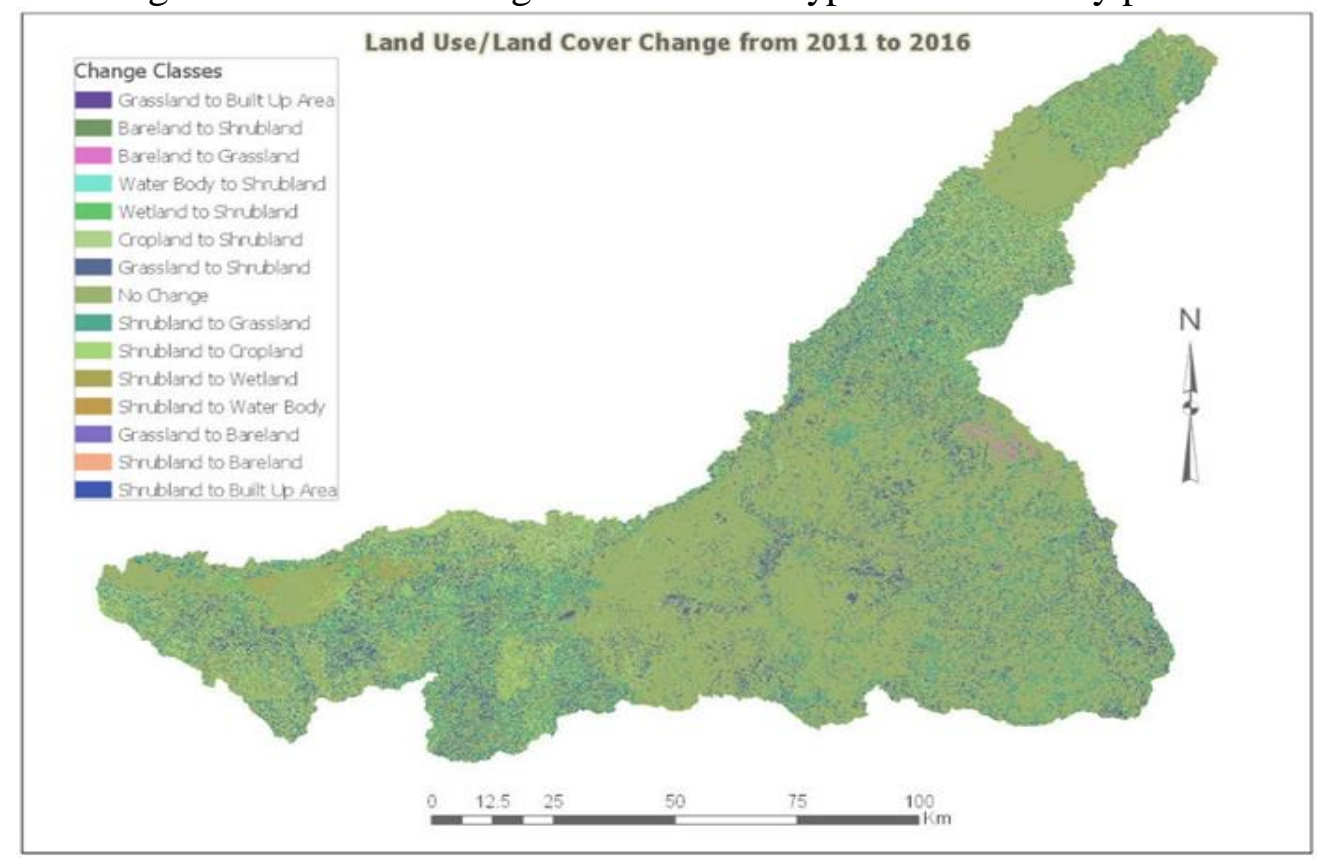

Figure 6: An overlay of 2011 and 2016 Maps (Source: Researcher, 2018)

\subsection{Trends and Magnitude of Land Cover Change in the Mara River basin}

The study reveals that, shrub land decreased while cropland and built-up area increased throughout the study period. Grassland and forestland also decreased all through except for the periods 1984-1995 that recorded an increase in grassland while 2003 to 2011 indicated a slight increase in forest cover. This scenario notwithstanding, the shrub land, grassland and forestland are facing a serious reduction in the basin, changing mainly to cropland and built-up areas. Between 1984 and 1995, a period of eleven years, forestland reduced by $0.44 \%$, shrub land by $3.34 \%$, wetlands by $0.31 \%$ and water body by $0.04 \%$, changing mainly to cropland, grassland and built-up area. The grassland, cropland built-up areas and bare land, gained in coverage by $1.65 \%, 2.46 \%, 0.01 \%, 0.01 \%$ and about $0.0001 \%$ respectively. The $1995-2003$, an eight year period reported close to double the reduction in the area under forest, $(0.85 \%)$ with shrub land and grassland decreasing almost with same value (2.19\% and 2.2\%). These classes changed to cropland and wetland, which recorded major increases, the period that also saw water bodies increase by quite a large magnitude $(3.07 \%, 1.61 \%$ and $0.61 \%$ respectively).

Table 3: Trends and Magnitude of Land Cover Change.

\begin{tabular}{|c|c|c|c|c|c|c|c|c|}
\hline \multirow{2}{*}{$\begin{array}{l}\text { Land } \\
\text { Cover } \\
\text { Types }\end{array}$} & \multicolumn{2}{|c|}{ 1984-1995 } & \multicolumn{2}{|c|}{ 1995-2003 } & \multicolumn{2}{|c|}{$2003-2011$} & \multicolumn{2}{|c|}{$2011-2016$} \\
\hline & $\begin{array}{l}\text { Hect } \\
\text { ares }\end{array}$ & $\%$ & Hectares & $\%$ & Hectares & $\%$ & Hectares & $\%$ \\
\hline Forestl & -6301.45 & -0.44 & $-\overline{12150.31}$ & $\overline{0}-85$ & 11734.88 & 0.83 & -129.96 & $\overline{0}-01$ \\
\hline
\end{tabular}


International Journal of Agriculture, Environment and Bioresearch

Vol. 5, No. 05; 2020

ISSN: $2456-8643$

\begin{tabular}{|c|c|c|c|c|c|c|c|c|}
\hline $\begin{array}{l}\text { Shrub } \\
\text { land }\end{array}$ & $\begin{array}{l}- \\
47738.40\end{array}$ & -3.34 & $\begin{array}{l}- \\
31292.91\end{array}$ & $\begin{array}{l}- \\
2.19\end{array}$ & -2741.52 & $\overline{0} .18$ & $\begin{array}{l}- \\
15982.38\end{array}$ & $-\overline{1.11}$ \\
\hline Grassland & 23934.27 & 1.65 & $\begin{array}{l}- \\
31543.24\end{array}$ & -2.2 & $\begin{array}{l}- \\
19279.34\end{array}$ & $-\overline{1.33}$ & $-\overline{28453.23}$ & $-\overline{1.98}$ \\
\hline Cropland & 35310.80 & 2.46 & 44024.01 & 3.07 & 31318.30 & 2.19 & 35689.86 & 2.5 \\
\hline wetland & -4429.79 & -0.31 & 23035.86 & 1.61 & $-\overline{14587.57}$ & $\begin{array}{l}- \\
1.02\end{array}$ & 7185.87 & 0.5 \\
\hline $\begin{array}{l}\text { Water } \\
\text { body }\end{array}$ & -446.91 & -0.04 & 8722.90 & 0.61 & -7911.13 & - & 575.46 & 0.04 \\
\hline $\begin{array}{l}\text { Built-up } \\
\text { Area }\end{array}$ & 158.71 & 0.01 & -186.11 & $\overline{0.01}$ & 281.29 & 0.02 & 587.97 & 0.04 \\
\hline Bare land & 14.58 & 0.001 & -600.28 & - & 738.61 & 0.05 & 421.20 & 0.03 \\
\hline
\end{tabular}

Alternating rise and fall in values of wetlands and water bodies could be attributed largely to variations in rainfall than human encroachment although both work in concert. A slight reduction in built-up area was recorded, which could be due to miss interpretation of the pixels during image classification exercise. The usual expectation is an increase in the built-up areas and not the opposite unless there were demolitions and other natural events that destroyed a whole settlement such as landslides. Figure 7 is a graphical representation the changes over the study period. 


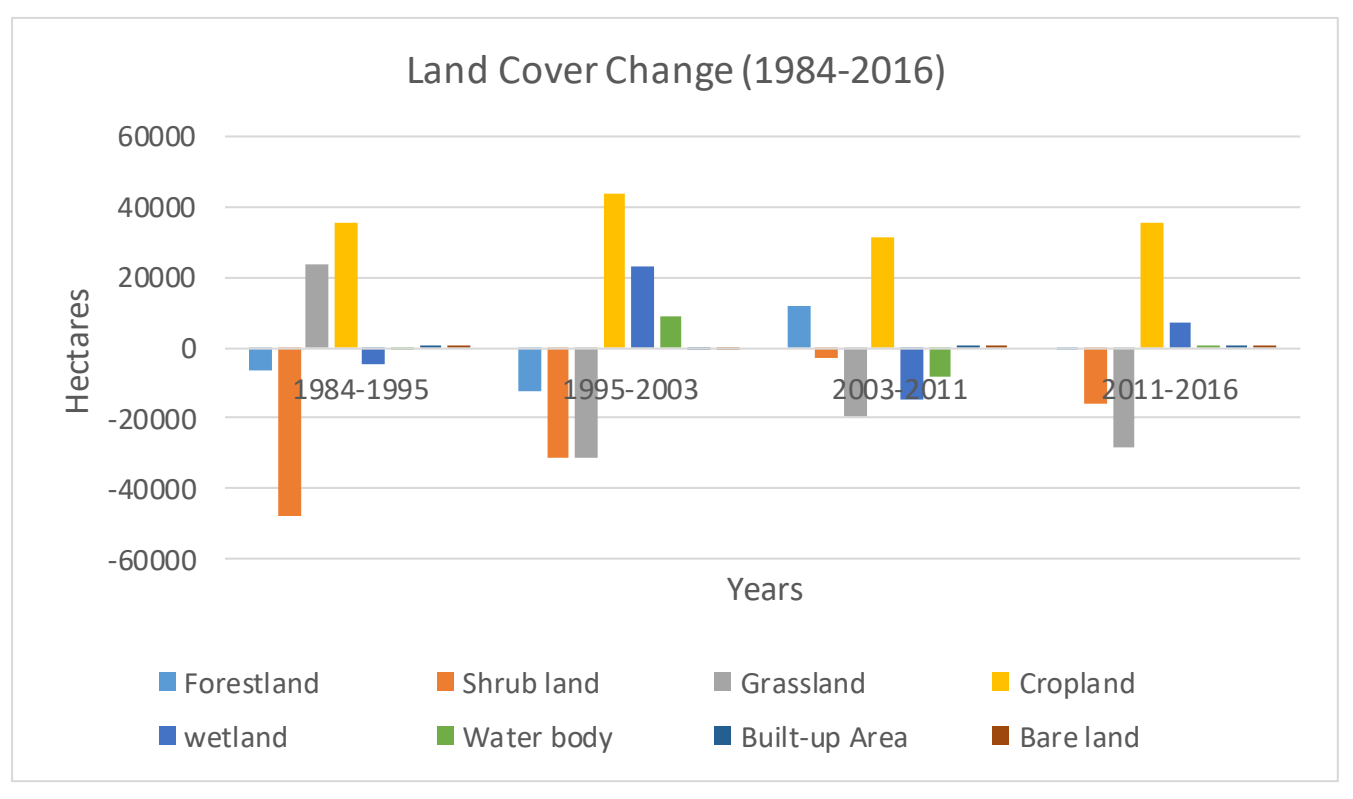

Figure 7: Land Cover Change (1984 - 2016)

The period 2003-2011, covering eight years witnessed changes contained in columns 6 and 7 of Table 3. The area under forest recorded the only increase of a small margin while shrub land and grassland continued to decline in their coverage. Wetlands and water bodies had no specific pattern in their variation between 1984 and 2016 with a decrease in each of them in one-period and then an increase in the next period (Table 3) to the end of the study. Their variations could have more to do with the weather patterns that prevailed during these periods, anthropogenic factors notwithstanding. The declining trends in forestland $(2011-2016)$ is a clear indication of poor management, of the forest ecosystem as well as the other ecosystems, as portrayed by their trends of change

\section{DISCUSSIONS}

The results on overlay operations revealed such a complex of changes in land cover and land use categories in which the eight classes changed within and across the classes giving about fifty-one classes including classes that did not change and those that changed from unclassified to specific class and vice versa. These changes are purely a result of human interventions in the basin, as population increased. From the literature reviewed in section one, the increasing trends in areas under crops is attributed to rapid increase in population in the basin orchestrated by the immigrant farming communities, developing agents and the government policy of privatizing the land ownership to change the lifestyle of the indigenous communities who are largely pastoral for the better. Thus, human interventions in this water scarce basin is both the result of individuals' eagerness to look for space to improve his living standard and at the same time, government intervention to improve her citizenry's economic status.

The effects of these changes are already being felt in the Mara basin and may be very costly in the end. For example, reduction in forestland, grassland and shrub land at the expense of cropland and built-up area are causing reduction in rainfall and river discharge as well as environmental degradation, which are a threat to the transboundary Mara resources, which 
require concerted efforts to conserve.Many studies including that by [19] indicated that conversion of forestland to cropland resulted in a 3.2\% reduction in the total annual river flow volumes while reduction of $20 \%$ in rainfall translated to a $46 \%$ annual flow reduction in the Mara basin. The study also discovered that base flows reduce significantly during dry seasons. Decreased stream flows could cause serious impact on the environment, the river and estuary ecosystems and, socioeconomic systems since the Mara River waters are dependent upon by almost every sector of the economy in the basin.

\section{CONCLUSION}

Forests perform many functions including being water towers, microclimate modifiers, control of surface runoffs and contributing to the aspects of energy balance in an ecosystem as well as improving the aesthetic values of the environment. Decrease in forest cover therefore would result in serious impacts on both the physical and cultural landscapes. If this were so in our case, we would expect a reduction in areas under wetlands and water bodies. The contrary is however the case, more so that forestland decreased in three out of four periods.

Land cover and land use types have significantly changed in the Mara River basin with decline in forestland, grassland and shrub land that converting to cropland and built-up areas. Wetlands and water bodies are also changing albeit, without a specific pattern. Reduction in forest cover, grass and shrubs have resulted in increased overland flows has resulted in increased erosion and destruction of environment, properties and loss of lives. Deforestation in the basin is causing reduction in evapotranspiration and therefore poor rainfall formation due to reduced linkage between the terrestrial hydrological cycle and the atmosphere. Thus, the reduction in rainfall and therefore, discharge witnessed in the Mara basin.

Reduction in forest cover also reduces or removes its ability to regulate microclimate and therefore, the rise in temperature experienced. Farming in fragile areas, especially rangelands and increased abstraction of the Mara waters as users increased on a background of decreasing rainfall and rising temperatures, has made the basin more vulnerable to the effects of human interventions and climate variability, mainly droughts and floods. It is therefore important put in place structures to mitigate or regulate the adverse impacts resulting from such scenarios, especially the impacts on the river flow volumes and water availability for the various water users in the basin. This is very important since Mara is trans-boundary with ecological, environmental and diverse livelihoods to support.

Author Contributions: IAO framed the research problem and the methodology and wrote a draft manuscript. GKO and SM supervised the study, contributed to the methodology, framing, and read and approved the manuscript. All authors have read and agreed to the published version of the manuscript."

Funding: "This research received no external funding"

Acknowledgments: The authors acknowledge support of Dr. Isaiah Nyandega for making the software available to the first Author and Dr. Boniface Wambua for moral support.

Conflicts of Interest:"The authors declare no conflict of interest." 
Vol. 5, No. 05; 2020

ISSN: $2456-8643$

\section{REFERENCES}

1. Wu, F.; Zhan, J.; Su, H.; Yan, H.; Ma, E. Scenario-Based Impact Assessment of Land Use/Cover and Climate Changes on Watershed Hydrology in Heihe River Basin of Northwest China. Adv. Meteorol.2015, 2015, e410198, doi:10.1155/2015/410198.

2. Yang, X.; Ren, L.; Liu, Y.; Jiao, D.; Jiang, S. Hydrological response to land use and land cover changes in a sub-watershed of West Liaohe River Basin, China. J. Arid Land2014, 6, 678689, doi:10.1007/s40333-014-0026-4.

3. Vitousek, P.M.; Mooney, H.A.; Lubchenco, J.; Melillo, J.M. Human Domination of Earth's Ecosystems. Science 1997, 277, 494-499, doi:10.1126/science.277.5325.494.

4. FAO Global Forest Resources Assessment 2010; Food and Agricultural Organization of the United States: Rome, Italy, 2010; p. 378;.

5. Wang, F.; Ge, Q.; Yu, Q.; Wang, H.; Xu, X. Impacts of land-use and land-cover changes on river runoff in Yellow River basin for period of 1956-2012. Chin. Geogr. Sci.2017, 27, 13-24, doi:10.1007/s11769-017-0843-3.

6. Baker, T.J.; Miller, S.N. Using the Soil and Water Assessment Tool (SWAT) to assess land use impact on water resources in an East African watershed. J. Hydrol.2013, 486, 100-111, doi:10.1016/j.jhydrol.2013.01.041.

7. Yin, J.; He, F.; Xiong, Y.J.; Qiu, G.Y. Effects of land use/land cover and climate changes on surface runoff in a semi-humid and semi-arid transition zone in northwest China. Hydrol. Earth Syst. Sci.2017, 21, 183-196, doi:https://doi.org/10.5194/hess-21-183-2017.

8. IPCC, T.C.W.T. IPCC, 2007: Climate Change 2007: Synthesis Report. Contribution of Working Groups I, II and III to the Fourth Assessment Report of the Intergovernmental Panel on Climate Change; IPCC: Geneva, Switzerland, 2007; p. 104;.

9. UNFCCC Fact sheet: Climate change science-the status of climate change science today 2011.

10. Dai, E.; Wu, Z.; Ge, Q.; Xi, W.; Wang, X. Predicting the responses of forest distribution and aboveground biomass to climate change under RCP scenarios in southern China. Glob. Change Biol.2016, 22, 3642-3661, doi:10.1111/gcb.13307.

11. Mango, L.M.; Melesse, A.M.; McClain, M.E.; Gann, D.; Setegn, S.G. Land use and climate change impacts on the hydrology of the upper Mara River Basin, Kenya: results of a modeling study to support better resource management. Hydrol. Earth Syst. Sci.2011, 15, 2245-2258, doi:https://doi.org/10.5194/hess-15-2245-2011.

12. Bradshaw, C.J.A.; Sodhi, N.S.; Peh, K.S.-H.; Brook, B.W. Global evidence that deforestation amplifies flood risk and severity in the developing world. Glob. Change Biol.2007, 13, 23792395, doi:10.1111/j.1365-2486.2007.01446.x. 
13. Ayuyo, I.O. Geospatial analysis of land cover and land use change in the Mau forest complex of Kenya. Thesis, University of Nairobi, Kenya, 2012.

14. Meyer, W.B.; Turner II, B.L. Changes in land use and land cover: a global perspective; University: Cambridge, 1994; ISBN 978-0-521-47085-8.

15. Wu, Z.; Dai, E.; Ge, Q.; Xi, W.; Wang, X. Modelling the integrated effects of land use and climate change scenarios on forest ecosystem aboveground biomass, a case study in Taihe County of China. J. Geogr. Sci.2017, 27, 205-222, doi:10.1007/s11442-017-1372-x.

16. Naef, F.; Scherrer, S.; Weiler, M. A process based assessment of the potential to reduce flood runoff by land use change. J. Hydrol.2002, 267, 74-79, doi:10.1016/S0022-1694(02)00141-5.

17. Brown, A.G.; Hatton, J.; O’Brien, C.E.; Selby, K.A.; Langdon, P.G.; Stuijts, I.; Caseldine, C.J. Vegetation, landscape and human activity in Midland Ireland: mire and lake records from the Lough Kinale-Derragh Lough area, Central Ireland. Veg. Hist. Archaeobotany2005, 14, 8198, doi:10.1007/s00334-005-0063-1.

18. Zhang, Y.-K.; Schilling, K.E. Increasing streamflow and baseflow in Mississippi River since the 1940s: Effect of land use change. J. Hydrol.2006, 324, 412-422, doi:10.1016/j.jhydrol.2005.09.033.

19. Melesse, A.M.; McClain, M.; Wang, X.; Abira, M.; Mutayoba, W. Modeling the Impact of Land-Cover and Rainfall Regime Change Scenarios on the Flow of Mara River, Kenya. 2012, 110, doi:10.1061/40976(316)558.

20. WREM, I. Mara River Basin Transboundary Integrated Water Resources Management andDevelopment Project Mara River Basin Monograph; 2008;

21. De Pauw, E. Consultant's final report on the soils, physiography and agroecological zones of Tanzania. 1984.

22. GoK Agricultural Sector Development Support Programme; Ministry of Agriculture: Nairobi, Kenya, 2011; p. 135;.

23. Aboud, A.A.; Obweyere, G.O.; Mutinda, M.M.; Raini, J.A. A Rapid Participatory Socioeconomic Assessment of the River Mara Basin: Mara River Catchment Basin Initiative; WWW-Eastern Africa Regional Programme Office: Nairobi, Kenya, 2002;

24. Mutie, S.M.; Mati, B.; Gadain, H.; Home, P. Land-cover Change Effects on Flow regime of Mara River. A paper presented and published in the workshop proceedings of Information System for Crisis Management (ISCRAM). In Proceedings of the 2nd International ISCRAM Conference; Van de Walle, B., Carle, B., Eds.; Information Systems for Crisis Management: Brussels, Belgium, 2005; pp. 237-246.

25. Mati, B.; Mutie, S.M.; Home, P.; Mtalo, F.; Gadain, H. Land Use Changes in the Transboundary Mara Basin: A Threat to Pristine Wildlife Sanctuaries in East Africa. In 
Proceedings of the 8th International River Symposium; International River Symposium: Brisbane, Australia, 2005.

26. Machiwa, P.K. Water quality management and sustainability: the experience of Lake Victoria Environmental Management Project (LVEMP)—Tanzania. Phys. Chem. Earth Parts $A B C 2003,28,1111-1115$, doi:10.1016/j.pce.2003.08.032.

27. Van der Meer, F.D. Imaging Spectrometry for Geological Applications. In Encyclopedia of Analytical Chemistry; American Cancer Society, 2006 ISBN 978-0-470-02731-8.

28. Coppin, P.R.; Bauer, M.E. Digital change detection in forest ecosystems with remote sensing imagery. Remote Sens. Rev.1996, 13, 207-234, doi: 10.1080/02757259609532305. 